\title{
Knowledge Management in Brazilian, Portuguese and Polish Organizations: a Comparative Analysis
}

Florinda Matos, ISLA - Higher Institute of Management and Administration of Santarém, Santarém, Portugal, florinda.matos@unisla.pt

Válter Vairinhos, ICLab - ICAA - Intellectual Capital Accreditation Association, Santarém, Portugal, valter.vairinhos@icaa.pt

Fábio Ferreira Batista, Instituto de Pesquisa Econômica Aplicada - Ipea, Brasília, Brazil, fabio.batista@ipea.gov.br

Joanna Paliszkiewicz, Warsaw University of Life Sciences, Warsaw, Poland, joanna_paliszkiewicz@sggw.pl

Maria do Rosário Cabrita, UNIDEMI, FCT, Universidade Nova de Lisboa, Portugal, m.cabrita@fct.unl.pt

\begin{abstract}
The knowledge emerges as a strategic factor that enables organizations to create wealth through the transformation of tacit knowledge into explicit knowledge. Knowledge Management (KM) activities are recognized as a critical issue for the development of innovation in the companies. However, KM is now a major challenge because, with the growth of available information, this task becomes increasingly complex. In addition, KM involves the management of organizational culture, based on principles of organizational learning. This paper presents the results of an exploratory study conducted among the decision makers of Portuguese, Brazilian and Polish companies and aims to determine the perception they have of the future needs of knowledge and information. We intended to identify future areas of research that can address the needs of knowledge that create conditions for a more sustainable business. Furthermore, this paper also aims to identify factors which could help to improve knowledge management practices in the three countries. The findings demonstrate that Portuguese and Polish managers are aware of the importance of KM as a determinant factor of business success, but KM is not frequently used in strategic decision making. Unlikely, the process of KM is a more common practice in Brazilian companies.
\end{abstract}

Keywords: Knowledge Management - KM Practices, Portugal, Brazil, Poland

\section{Introduction}

This paper is an exploratory study conducted to identify differences and similarities about how Brazilian, Portuguese and Polish KM experts and practitioners see theoretical and practical KM issues as well as about their definitions or understanding of the concepts of "knowledge" and "knowledge management." 
The theoretical issues under analysis are: (i) the most important advancement; (ii) the most pressing and challenging issue for the understanding and advancement of KM, and; (iii) which approach is most likely to deal effectively with the appointed research issue.

Experts and practitioners were also asked to share their views on the following practices issues: most recent practical advancement in $\mathrm{KM}$; most pressing and challenging problem for the understanding and advancement of KM; and approach and/or organization is most likely to deal effectively with the nominated problem.

We have not found early studies, neither in Brazil nor in Portugal or Poland, to which we could refer for information about the KM issues analyzed here. Therefore, the exploratory nature of this paper is well established as well as the attempt to bridge the existing gap in KM literature in the three countries.

\section{Literature Review}

\section{Critical Issues for Knowledge Management Implementation}

In a world of dynamic and discontinuous change, organizations are constantly seeking ways to adapt themselves to new conditions so that, they are prepared to survive and flourish in a competitive marketplace. Knowledge, as the productive factor (Drucker, 1998), is increasingly accepted as a critical competitive asset, a source of value creation and a differentiator between firms (Nonaka, 1991; Carlucci and Schiuma, 2006; Viedma and Cabrita, 2012). Knowledge management (KM) has become a very popular topic of research (Davenport and Prusak, 1998; Senge 1990; Liebowitz, 2008, 2012). The challenge for companies requiring participation in knowledge-intensive sectors of the global company is to organize themselves so that they can reexamine and rearrange their culture, structures, information technologies, and business processes from a knowledge perspective. By implementing knowledge management initiatives, organizations expect to gain the capability of managing their knowledge and, ultimately, to achieve superior performance. Despite the active interest in managing organizational knowledge as a strategic resource, most organizations do not yet understand the challenges involved in implementing KM initiatives. In addition, the literature (Bedward et al., 2003; Glisby and Holden, 2003) suggests that KM practices have to be viewed in the context of local cultures. In an organization, managers bring values, experiences and beliefs that are profoundly rooted in their national culture, which forms personal reference frame (Frost and Walker, 2007). Then, the success of KM implementation programs is largely dependent on organizational and national cultural contexts. The implementation of a KM programs involves the creation, acceptance, and adoption of processes, values, and systems that are either company-wide or in the very least span across functions, departments, and communities. The implementation and long-term success of such far-reaching changes require top and central management backing, both from the perspective of resource and political support but also to ensure day-to-day acceptance of such measures.

In order to develop an effective system of $\mathrm{KM}$ within an organization, the first step is to understand the way individuals perceive knowledge. For instance, Jakubowicz and Rendón (2012) explore KM practices in some South American organizations operating in Spanish 
speaking countries and found that organizations have little awareness (or concern) of seeing and/or seeking the relation between KM and organizational strategy development.

Apart from cultural differences, the governing aspects of a $\mathrm{KM}$ project include areas such as management support, organizational culture, and organizational structure. Since culture has the potential to impact on business activities of companies, KM practices can also be affected by cultural differences. Culture and cultural differences are important issues for every organization in every industry. Therefore, KM implementation differs from one country to another.

\section{Knowledge Management in Brazil}

Several studies and research in KM were performed in the last fifteen years in Brazil. Such works can be divided into three categories: case studies of implementation of KM in public and private organizations for academic purposes; books published for commercial purposes to report KM implementation experiences; and analysis of how the Brazilian federal government has been treating the subject since 2004. In the first two categories are included a vast production of master's and doctoral theses, as well as works that have reported cases of successful implementation of KM. Studies of Angeloni, (2008), Alvarenga, (2002) Passion (2004) Botelho (2009), Miranda (2010) Gomes (2005) Alencar and Fonseca (2013) Rezende (2014) are among others. The third category comprises studies and research carried out by the Applied Economic Research Institute (IPEA) in order to evaluate how KM has been seen and applied by the Brazilian federal government since 2003 (Batista, 2004; Batista et al., 2005; Batista, 2006; Batista et al, 2007;. Batista, 2012; Batista et al, 2014; Batista et al, 2015; Batista, 2015b, and Batista et al, 2015c).

The pioneering nature of this work in Brazil is due to the fact that never before have been conducted research in order to capture the perception of experts both in academia and the corporate world on important topics to search now and in the future in the area KM.

\section{Knowledge Management in Portugal}

In Portugal, there are few public or private organizations with formal programs of KM when defined as a set of coordinated initiatives, interconnected and aligned with the organizational strategy that aims to promote the acquisition, creation, archiving, retrieving, sharing, evaluation and use of operating knowledge, there are few organizations that do not create initiatives directed to one or more of these aspects.

According to Silva and Neves (2003), the Portuguese organizations are reluctant to risk themselves in a more formal and especially more intensive and systematic way in KM for the following reasons: there is generally a passive attitude in Portugal regarding what is happening in other countries; there is a low level of academic training in the majority of the employed population; the country's competitiveness is considered to be low; there is an exaggerated importance given to the rank and academic titles; insufficient good examples of leadership in relation to the creation and trusted environments; there are strong sub-cultures, well-creased in Portuguese organizations with divisions between hierarchical levels; international economic situation marked by great uncertainty; the technology lacks emphasis; the national culture is mainly concerned with short-term goals; there are very few metrics for evaluating the programs of knowledge management. 
Brito and Cardoso (2009) after an empirical study in the area of public administration and industry in Portugal, consider the "practical knowledge management" beneficial when aiming at enhancement of knowledge, not only with the aim of promoting the creation and acquisition of knowledge but also considering its use and preservation. Knowledge management in Portuguese organizations must reside in a deep understanding of the particularities and requirements of the environment of organizations, individual and collective needs of the employees and all the processes involved in creating and learning (Pepper \& Carvalho, 2004).

Eiriz, Simões, and Gonçalves (2007), in a study of KM in higher education in Portugal, enumerated three factors as obstacles to knowledge management: 1) leadership and organization; 2) communication; and 3) organizational resources. Costa (2013) studied the efficacy of knowledge management in SMEs and concluded that this is a determining factor.

Matos and Miguel (2013), in a survey conducted in Portugal, conclude that there is awareness about the importance of using good practices of knowledge management, but these practices are still at a very early stage. Guiomar (2014) in a study in a Portuguese company analyzed the benefits of implementing a Corporate Portal facilitator of innovation, based on knowledge management. The lack of studies on knowledge management in Portugal can be seen as a status indicator of management practices on this subject.

\section{Knowledge Management in Poland}

In the information age, knowledge is the most valuable asset and the only source of sustainable competitive advantage. In Poland, many researchers have conducted studies in the field of knowledge management(e.g., Skrzypek 1999; Kisielnicki 2003; Grudzewski, Hejduk 2004; Mikuła 2006, Kowalczyk, Nogalski 2007; Paliszkiewicz 2007; Jemielniak, Koźmiński 2008; Gierszewska 2011). According to Skrzypek (2000), knowledge management is related to all process of creativity, innovation, learning, developing of employees as well as to IT technologies. Kotarba (2006) described the main objectives of knowledge management as assistance in acquiring, gathering and using knowledge to achieve success, competitive advantage and increase goodwill and wealth of the company. Paliszkiewicz (2007) proposed following processes of knowledge management: 1) localization - refers to all activities that indicate where knowledge exists; 2) usage of knowledge - refers to creating a set of roles and skills to effectively use of knowledge; 3) knowledge acquisition and development - refers to the culture of embracing the knowledge that is acquired and developed; 4) knowledge codification refers to the ability to successfully and continuously re-use the knowledge organizations capture, and 5) knowledge transfer - refers to transmission of knowledge and use of the transmitted knowledge. Wyrozębski (2014) wrote a book about knowledge management in relation to project management. Trajer, Paszek, Iwan (2012) focused on practical implementation of knowledge management tools in organizations. Soniewicki (2015), described the role of knowledge orientation for the competitive advantage of a company in the process of internationalization. Chmielecki (2012) wrote about cultural barriers of knowledge management in an example of Poland and proposed some ways how to overcome them. Many authors underline the benefits which bring knowledge management to the companies (Kowalczyk, Nogalski 2007, Gierszewska 2011, Paliszkiewicz 2007). For example, according to Brdulak (2012), the benefits are more effective learning from internal and external stakeholders, more effective implementation of 
changes, faster response to events in the external environment, more effective activity in nonstandard situations.

\section{Empirical Research}

Based on the objectives of this exploratory research, identification of field analysis was conducted, composed "by the opinion of 13 Portuguese opinion makers ", "by the opinion of 10 Brazilian opinion makers" and "by the opinion of 5 Polish opinion makers". These opinion makers are considered experts in the field of knowledge management.

"Experts" were defined as people being active in knowledge management research or practice, in the last five to ten years at least (Scholl, König, Meyer \& Heisig, 2004, p. 20). Among them were managers and professors.

The sample was determined using a targeted sampling method, being chosen the field analysis depending on the features and accessibility.

Semi-directed interviews were applied since this was the technique that best guarantees the collection of as much information about the problem under investigation.

This research is a part of a European project of the Socio-Technical Centre Leeds - STC, of Leeds University Business School, and it aims to identify the future needs of knowledge. It is intended to identify future areas of research that can address the needs of knowledge, creating conditions for a more sustainable business.

The survey used in this research as well as research procedures were supported by the Global Knowledge Survey methodology (Heisig 1999, 2012).

The interview is organized into the following sections:

A. Demographic Data

B. Achievements - Challenges - approach in theory and practice of Knowledge Management

C. Basic Concepts: Knowledge and Knowledge Management

D. Research Needs Knowledge Management Dimensions

E. Chronogram of research 2015 - $2020-2025$

Given the length of the survey, with some very extensive interviews, in this paper we will only analyze the part of the research (Achievements - Challenges - approach in theory and practice of Knowledge Management). The other topics will be part of another paper.

\section{Results}

\section{Achievements - Challenges - approach in theory and practice of Knowledge Management}

\section{Question 1. What is the most important recent theoretical advancement in KM?}

In Portugal, the most important theoretical advance in this area considers the transfer of knowledge models, new technologies of information and communication, practices and methods of knowledge management processes. 
In Brazil, the theoretical advances are more focused in the decision-making process, in the use of knowledge management in public administration and, particularly, in knowledge management as a strategic tool.

In Poland, only two interviewees answered the question, and they consider relevant "the theory of stakeholders and the theory of social network analysis." Also, they consider important the attempt at harmonization of the concept by some authors.

\section{Question 2. What is the most pressing and challenging theoretical research issue for the understanding and advancement of KM?}

In Portugal, the most pressing and challenging theoretical research issues are: The translation of the value of knowledge as a critical asset for organizations; Development of information technology; Importance of KM for success and innovation; Relationship between retention practices, dissemination and appropriation of knowledge with the innovative capacity; the need to demonstrate the specific effects of the implementation of a strategy organizational that goes through knowledge management, the link of knowledge management (operational level) with the intellectual capital (strategic level) and its measurement; Nonaka Theory; Measuring intangible capital and its impact on organizations.

In Brazil, the most pressing and challenging theoretical research issue is how to manage knowledge, how to implement KM, how to motivate people, and how to get involved in KM initiatives (internal and external motivation to participate in KM projects). How to measure KM organizational impact (results), identification of explicit knowledge forms (automatized processes and documented procedures) as an alternative to the tacit knowledge; KM policies for public administration; Design of an information framework in the field of Science, Technology and Innovation; KM concepts, attributes and relevance in the public administration; KM methodologies in organizations; The use of information practices in health research and management; Motivation attitudes aspects for knowledge sharing to create organizational knowledge; KM as strategic input; The complexity and Intangible Management; Sharing knowledge.

In Poland, the most pressing and challenging theoretical research issue is the cognitive theory which attempts to explain human behaviour by understanding the thought processes, the cultural norms supporting multiplication and exchange of knowledge, the personalization strategy of knowledge transfer, the role of the transfer process, the measuring of the effectiveness of solutions for knowledge management, innovation, and knowledge, the organizational structures to support knowledge management process and continuous transformation of tacit knowledge.

\section{Question 3. Which theoretical approach and/or scientist is most likely to deal effectively with this theoretical research issue?}

In Portugal, the theoretical approach is the social construction of knowledge based on the Nonaka Model; anything that contributes to a better understanding of the continuum: tacit knowledge, explicit knowledge, individual learning and collective learning.

In Brazil, the theoretical approach is the KM view as an organizational process; tacit knowledge, explicit knowledge; Public administration expert; Communication experts; Information scientists; Systems 'analysts; Complexity Sciences; Educational Psychology, Andragogy, Corporate Education and Knowledge Strategic Management. 
In Poland, the theoretical approach is the "cognitive theory" which attempts to explain human behavior by understanding the thought processes and the approach of people as capital.

\section{Question 4. What is the most important recent practical advancement in KM?}

In Portugal, the most important practical advances were artificial intelligence; incorporation of KM digital tools in business; development of web platforms with management capacity, editing and updating information in a decentralized way; development of KM systems; development of technologies and software.

In Brazil, the most important practical advances were maturity frameworks; the emergence and improvement of KM technological facilitation tools (such as Share Point); the development of collective creation and services (example: several types of crowdsourcing) and their acquisition and management processes; knowledge mapping methodologies (example: Knowledge Tree); the recognition by managers of companies, that is no longer possible to ignore this issue; the upgrading and management of critical knowledge and intellectual capital in organizations.

In Poland, the most important practical advances are the concept of social network analysis, the capacity to channel the relevant knowledge to constructive ends, the technological ability to store and search significantly bigger volumes of data and the construction of knowledge management systems for a selected area of practical activity (such as software development).

\section{Question 5. What is the most pressing and challenging practical problem for the} understanding and advancement of knowledge management?

In Portugal, the most pressing and challenging practical problem is knowledge as a factor of value creation and the incorporation of the various tools KM in daily business, the approach of humanist perspective; knowledge sharing; understand the benefits of knowledge management; the development of technologies.

In Brazil, the most pressing and challenging practical problem is how to establish a link between KM and organizational purposes and results, how to involve people in KM activities and initiatives, how to measure KM financial and strategic returns for organizations in a more exact and reliable way, the identification of direct links between KM activities and business results in the short, middle and long-term; methodologies that assure knowledge that come from KM practices integration to organizational processes and innovation; intangibles management; do business leaders understand that KM projects must be very aligned with the strategy of companies; mapping directly processes related to internal communication and information management in large enterprises.

In Poland, the most pressing and challenging practical problem is how to take advantage of software tools in knowledge management, how to identify relevant informal knowledge on the macro knowledge level, how to manage and store the unlimited volume of data and how to define the correct stages of designing and implementation of knowledge management systems

\section{Question 6. Which practical approach and/or organization are most likely to deal effectively with this practical problem?}

In Portugal, the practical approach is the benchmarking of methodologies; human resources training; research and constant innovation, to involve the employees in knowledge management 
strategy; creation of ad hoc programs for sharing knowledge through documentation, conducting training for their holders, participation in projects across.

In Brazil, the practical approach is to consider the organizational environment where $\mathrm{KM}$ is implemented; KM as a process with goals and metrics for each stage; the strategic representation in strategic maps; KM integration to the organizational management framework, to create metrics that effectively demonstrate the link between the KM and corporate results, to consider the involvement of leaders; to promote an organizational culture centred in KM; systems analysis focused on mapping the KM processes

In Poland, the practical approach is the cooperation with IT specialists, the improvement of KM measures to promote the participation of the people in the organization and the guarantee of consistency of the KM used in different projects.

\section{Conclusions}

The main similarities found in the interviews of Brazilian, Portuguese and Polish KM experts and practitioners concerning the state of knowledge management in the three countries were: (i) the state of theories is similar; (ii) there is a common understanding that organizational outcomes (innovation and competitive advantage) as a result of KM implementation is still a challenge to be overcome; and, (iii) the transformation of tacit knowledge in explicit knowledge to create value in business processes, products and services is a common concern.

On the other hand, the major differences were: (i) in Brazil the KM practices and the recognition of its strategic importance are much more developed; (ii) in Poland and in Portugal KM is still in a very early state, and it is practically focused on theoretical and academic aspects, and; (iii) In Brazil, KM programs are more developed, and the federal government itself is concerned with KM implementation.

In Portugal and in Brazil, the transformation of tacit knowledge in explicit knowledge is a common topic. However, in Brazil, the KM is linked to different areas and sciences. In Poland, the topic is more centered in the behavior and the approach of people as capital.

In Portugal and Poland, the practical advances in KM are more centered on the technologies and software than in Brazil, where other KM tools and practices are more significant. Poland also considers the concept of social network analysis as relevant.

In the three countries, the most pressing and challenging practical problem for the understanding and advancement of knowledge management is centered in $\mathrm{KM}$ as a factor of value creation in the businesses, in the KM tools and in KM sharing. In Brazil, the KM problems seem to be more developed than in Portugal and Poland.

In Portugal, Poland, and Brazil, the issues are similar (methodologies; training; to involve people; strategy, sharing KM), but in Brazil, the topics seem to be more developed.

This study was of exploratory nature, but could be the basis to identify critical success factors in KM implementation to be shared in both countries. For the advantage of theorists and academics, a more in-depth joint study about the theoretical advancements as well as about concepts of knowledge and knowledge management could help to improve the state of the art of KM literature in Brazil, Poland, and Portugal. 
According to the results of this exploratory study, we can conclude that the state of the art in Poland and Portugal is very similar and focused in the academic area, although in Brazil there are more practical experiences both in the public and in the private sector.

\section{References}

Alvarenga, N.R.C.D. (2002). Gestão da Informação e do Conhecimento nas Organizações: Análise de Casos Relatados em Organizações Públicas e Privadas. UFMG, Belo Horizonte.

Angeloni, M.T. (2008). Gestão do Conhecimento no Brasil: Casos, Experiências e Práticas de Empresas Públicas. Qualitymark, Rio de Janeiro.

Bardin, L. (2009). Análise de Conteúdo. Lisboa: Edições 70.

Batista et. al. (2005). Gestão do Conhecimento na Administração Pública. Ipea (Texto para Discussão 1095), Brasília.

Batista et. al. (2007). Gestão do Conhecimento em Organizações Públicas de Saúde. Ipea (Texto para Discussão no 1316), Brasília.

Batista, et. al. (2014). Casos reais de implantação do Modelo de Gestão do Conhecimento para a Administração Pública Brasileira. Ipea (Texto para Discussão no 1941), Brasília.

Batista, F. F. (2004). Governo que Aprende: Gestão do Conhecimento em Organizações do Executivo Federal. Ipea (Texto para Discussão no 1022), Brasília.

Batista, F. F. (2006). O desafio da gestão do conhecimento nas áreas de administração $e$ planejamento das Instituições Federais de Ensino Superior (Ifes). Ipea (Texto para Discussão no 1181), Brasília.

Batista, F. F. (2012). Modelo de Gestão do Conhecimento para a Administração Pública Brasileira: como implementar a GC para produzir resultados em benefício do cidadão. Ipea, Brasília.

Batista, F. F. e Matos, F. (2014). Knowledge management in public administration: Brazil versus Portugal. Proceedings of the 15th European Conference on Knowledge Management. Santarém, Portugal.

Bedward, D., Jankowicz, D., Rexworthy, C. (2003). East meets west: A case example of knowledge transfer. Human Resource Development International, 6(4), 527-545.

Brito, E. \& Cardoso, L. (2009). Knowledge Management and Total Quality Management. In Applying Psychological Research to Understand and Promote the Well-being of Clinical and Non-clinical Populations, ed. K. A. Fanti, (pp. 161 - 174), Atenas: Atiner Publications.

Cardoso, L. \& Peralta, C.F. (2010). An Integrated Model of Knowledge Management: Frm Development of a Short-Form of KMQ to Empirical Validation of the Model. Proceedings of 11th European Conference on Knowledge Management, Vila Nova de Famalicao, Portugal. 
Carlucci, D. \& Schiuma, G. (2006). Knowledge Value Spiral: Linking Knowledge Assets to Company Performance, Knowledge and Process Management, 13(1), 35-46.

Davenport, T. H., \& Prusak, L. (1998). Working knowledge, Boston, MA: Harvard Business School

Drucker, P. (1998). The Coming of the New Organization, Harvard Business Review on Knowledge Management, Harvard Business School Press, MA.

Eiriz, V., Simões, J., Gonçalves, M. (2007). Obstáculos à gestão do conhecimento nas escolas de gestão e economia do ensino superior público em Portugal. Comportamento Organizacional e Gestão, 13(2) 153-167.

Frost, J. \& Walker, M. (2007). Cross cultural leadership. Engineering Management, 17(3), 2729.

Furquim, T. De A. \& Amaral, S. A. (2010). Knowledge management practices in Brazilian software organizations: the case of Serpro in Al-Shammari, Minwir. Knowledge management in emerging economies: social, organizational and cultural implementation. Hershey: Information Science Reference.

Gierszewska, G., (2011). Zarządzanie wiedzą w przedsiębiorstwie [Knowledge management in enterprise], Oficyna Wydawnicza Politechniki Warszawskiej, Warsaw.

Glisby, M. \& Holden, N. (2003). Contextual constraints in knowledge management theory: The cultural embeddedness of Nonaka's knowledge-creating company. Knowledge and Process Management, 10(1), 29-36.

Grudzewski, W. M. \& Hejduk, I. K., (2004). Zarządzanie wiedza w przedsiębiorstwach [Knowledge management in enterprises], Difin, Warsaw.

Guiomar, T. F. M. (2014). Gestão do conhecimento: a importância da inovação e da competitividade numa organização do séc. XXI. Dissertação de Mestrado, Universidade de Coimbra, Coimbra, Portugal. Retrieved April 05, 2015 from https://estudogeral.sib.uc.pt/bitstream/10316/27216/1/MICNM_Tese_TiagoFilipeGuioma r.pdf.

Heisig, P. (2014). Harmonisation of knowledge management - comparing $160 \mathrm{KM}$ frameworks around the globe. Journal of Knowledge Management, 13, 4-31.

Heisig, P. (2014). Knowledge management - advancements and future research needs - results from the Global Knowledge Research Network study. British Academy of Management 2014. Conference Proceedings.

Jakubowicz, D. M. \& Rendón, M. B. (2012). An Empirical and Modeling Approach to Knowledge Management Practices in South American Organizations. In Huei Tse Hou (Ed.) New Research on Knowledge Management Applications and Lesson Learned, (pp. 85-106), InTech, Croatia

Jemielniak, D. \& Koźmiński, A. K., (2008), Zarządzanie wiedzą [Knowledge management], Wydawnictwa Akademickie i Profesjonalne, Warsaw. 
Kisielnicki, J., (2003). Systemy pozyskiwania $i$ zarządzania wiedza we wspótczesnych organizacjach [Systems of acquisition and knowledge management in modern organizations], in: ed. J. Kisielnickiego, Zarzadzanie wiedza we wspótczesnych organizacjach [Knowledge management in modern organizations], Oficyna Wydawnicza Wyższej Szkoły Handlu i Prawa im. R. Łazarskiego, Warsaw.

Kotarba, W., (2006). Istota zarzadzania wiedza [The essence of knowledge management], [In:] Ochrona wiedzy a kapitał intelektualny organizacji [Protection of knowledge and the intellectual capital of organizations], (Ed). W. Kotarba, M. Kotarba, Polskie Wydawnictwo Ekonomiczne, Warsaw.

Kowalczyk, A. \& Nogalski, B. (2007). Zarzadzanie wiedza. Koncepcja i narzędzia, [Knowledge management. Concepts and tools] Difin, Warsaw

Liebowitz, J. (ed.) (2008). Making cents out of knowledge management, The Scarecrow Press, INC., Lanhman, Maryland, Toronto, Plymouth, UK

Liebowitz, J. (ed.) (2012). Knowledge Management Handbook. Collaboration and Social Networking, CRC Press, Taylor and Francis Group, Boca Raton, London, New York

Matos, F., \& Miguel, I. (2013). Knowledge management and competitive strategy. In Global Business and Technology Association, 761 - 767.

Mikuła, B. (2006). Organizacje oparte na wiedzy [Knowledge base organizations], Wydawnictwo Akademii Ekonomicznej w Krakowie, Cracow.

Nonaka, I. (1991). The Knowledge Creating Company, Harvard Business Review, NovemberDecember, 96-104.

Oliveira, M., Curado, C., Romão, M., e Maçada, A. C. G. (2014). Knowledege sharing: Brazilian $\mathrm{x}$ portuguease companies. Proceedings of the 15th European Conference on Knowledge Management, Santarém, Portugal.

Paliszkiewicz, J., (2007). Knowledge management: An integrative view and empirical examination, Cybernetics and Systems, 38(8), 825-836.

Paliszkiewicz, J., (2007). Zarządzanie wiedzą w małych i średnich przedsiębiorstwach koncepcja oceny i modele [Knowledge management in small and medium enterprises the concept of assessment and models] Wydawnictwo SGGW, Warsaw.

Scholl, W., König, C., Meyer, B. \& Heisig, P. (2004). The Future of Knowledge Management An international Delphi Study. Journal of Knowledge Management, 8, 19-35.

Senge, P. M. (1990). The Fifth Discipline, Doubleday/Currency.

Silva, R. V. \& Neves, A. (2003). Gestão de Empresas na Era do Conhecimento. Lisboa: Edições Sílabo.

Skrzypek, E., (1999). Wpływ zarządzania wiedzą na jakość, Problemy Jakości, 11.

Skrzypek, E., (2000). Jakość i efektywność, [Quality and effectiveness] Wyd. UMCS, Lublin.

Soniewicki, M., (2015). The company's international competitive advantage, Difin, Warsaw 
Trajer, J., Paszek, A., \& Iwan, S., (2012). Zarządzanie wiedzą [Knowledge management] PWE, Warsaw.

Viedma, J.M. \& Cabrita, M.R. (2012). Entrepreneurial Excellence in the Knowledge Economy: Intellectual Capital Benchmarking Systems (ICBS). UK: Palgrave Macmillan.

Wyrozębski, P., (2014). Zarządzanie wiedzą projektową [Project knowledge management], Difin, Warsaw.

\section{Authors' Biographies}

Florinda Matos is Ph.D. in Social Sciences, Organizational Behavior Studies by Technical University of Lisbon. She has a master's degree in business sciences by ISCTE - IUL Business School, an Engineer's degree in Agricultural Engineering and a Licentiate degree in Management of Agricultural Business by Polytechnic Institute of Santarém. She teaches several disciplines in graduate and post-graduate courses and she is a partner and a business consultant in the company PMEConsult. Her main research interests are: Knowledge Management, Intellectual Capital, Measuring of Intangibles, Marketing Strategy, Innovation and Entrepreneurship. Currently, she is ICAA's (Intellectual Capital Accreditation Association) president and she is leading the ICLab - Research Center in Intellectual Capital.

Válter Vairinhos. Retired Portuguese Navy officer where he served as a naval engineer between 1964 and 2009. He got his Naval Engineer Degree from Portuguese Naval School, an Applied Mathematics Degree (Licenciatura), and a Master's degree in Statistics and Operations Research from Faculdade de Ciencias, Lisbon Classic University and a Doctoral Degree - in Multivariate Data Analysis - from the Statistics Department, Salamanca University. Currently he shares his investigation activity between ICAA-Santarem and the Departamento de Estatística, Salamanca University. His main investigative interests are related with graph data mining and automatic synthesis of results from multivariate data analysis, being the author of a methodology, based in intersection graphs, to generate automatic synthetic descriptions of results from multivariate data analysis and its implementation through a software (BiplotsPMD) where those ideas are put to use.

Fábio Ferreira Batista. Senior researcher at the Institute of Applied Economic Research (Brasília, Brazil). Professor and researcher at Catholic University (Brasilia, Brazil). Professor at National School of Public Administration (Brasilia, Brazil). Ph.D in Information Science, University of Brasilia. Field of research: Knowledge management in the public sector. Certified Knowledge Manager by the Knowledge Management Institute - KMI (Washington, DC, EUA). Author of the book: Knowledge Management Framework for the Brazilian Public Administration (2012). Editor of the book: International Experiences of Knowledge Management Implementation (2016). $2^{\text {nd }}$ place in the Knowledge Management and Intellectual Capital Excellence Awards - 2015 with the case: IPEA's Knowledge Repository. Head of the Department of Knowledge and Quality Management of Ipea. Consultant in the field of Knowledge Management in the public sector.

Joanna Paliszkiewicz is a specialist in management issues connected with knowledge management, intellectual capital and trust management. She holds the rank of University 
Professor of Warsaw University of Life Sciences and Polish-Japanese Academy of Computer Technologies. Prof. J. Paliszkiewicz is well recognized in Poland and abroad with her expertise in management issues. She has published over 150 original papers and 3 books. She serves on the editorial board of several international journals. She is the deputy editor-in-chief of Management and Production Engineering Review Journal. Dr. Paliszkiewicz was named the 2013 Computer Educator of the Year by IACIS.

Maria Rosário Cabrita. Ph.D. in Business Administration (Institute of Economics and Business Administration, Lisbon Technical University). She is Assistant Professor and researcher at the Universidade Nova de Lisboa. She is also Assistant Professor at the Portuguese Banking Management School in Lisbon and in ISCTE-Business School. She teaches several disciplines in graduate and post-graduate courses. She has more than 50 published articles in conferences, book chapters and scientific specialized journals. She is co-author, with Prof. José Maria Viedma, of the book entitled Entrepreneurial Excellence in the Knowledge Economy: ICBS: Intellectual Capital Benchmarking System. 